\title{
Identifikasi dan Kemampuan Jamur Endofitik Asal Jagung (Zea mays L.) Terhadap Patogen Busuk Pelepah (Rhyzoctonia solani)
}

\author{
Identification and Ability of Endophytic Fungus from Corn (Zea mays L.) Against Midrib Rot \\ Pathogens (Rhyzoctonia solani)
}

\section{Shiska M. Rotasouw, Johana Taribuka*, Handry R.D. Amanupunyo}

\author{
Program Studi Agroteknologi, Jurusan Budidaya Pertanian, Fakultas Pertanian, Universitas Pattimura \\ J1. Ir. M. Putuhena, Kampus Poka, Ambon 97233, Indonesia \\ *E-mail Penulis Korepondensi: anontari@yahoo.com
}

\begin{abstract}
Maize is a cereal crop which is an important source of food because it is the second source of carbohydrates after rice. Maize cultivation is faced with various plant diseases, that can reduce the quantity and quality of crop yield. Plant disease is one of the limiting factors for crop production and seed quality. One of the most harmful maize diseases is blight or midrib rot caused by the soil-borne fungus Rhizoctonia solani. The aim of the study was to obtain endophytic microorganisms in maize and to test the antagonistic ability of these fungi as biological control agents against R. solani. The study took place in January-September 2018 in the field and the Laboratory of Plant Pests and Diseases, Faculty of Agriculture, University of Pattimura. Endophytic fungi isolated from maize plants from the roots, stems and leaves. Samples were cleaned in running water and air-dried. Subsequently, the samples were sterilized using 70\% alcohol and immersed in sodium hypochlorite solution for 2 minutes and rinsed with sterile water 3 times. The sterilized roots, stems and leaves of maize were peeled, cut to a size of $\pm 5 \mathrm{~mm}$, split and dried on sterile filter paper. Sterile samples were grown on PDA culture media at four points and incubated at room temperature. Visual identification was carried out with the aid of a microscope on fungi growing on the culture media. The results showed the presence of the endophytic fungi Trichoderma sp., Aspergillus sp., Penicillium sp., Diplodia sp. and Mucor sp. These fungal species showed different inhibitory powers, which included mechanisms for direct parasitizing of pathogens, producing antibiotics and competition for space and nutrients.
\end{abstract}

Keywords: antagonism, corn, endophytic fungi, identification, pathogenic fungus, Rhizoctonia solani

\section{ABSTRAK}

Jagung (Zea mays L.) merupakan tanaman serelia yang termasuk bahan pangan penting karena merupakan sumber karbohidrat kedua setelah beras. Salah satu kendala dalam budidaya tanama jagung adalah penurunan produksi akibat serangan patogen penyebab penyakit. Untuk menekan perkembangan penyakit dilakukan pengendalian dengan menggunakan mikroorganisme endofitik asal akar, batang dan daun jagung sebagai agensia pengendalian hayati. Penelitian ini bertujuan mengisolasi dan mengidentifikasi mikroorganisme endofitik asal jagung secara morfologi, mendapatkan mikroorganisme endofitik yang memiliki kemampuan antagonis terhadap jamur Rhizoctonia solani penyebab penyakit busuk pelepah pada jagung. Penelitian berlangsung dalam 2 tahap, yaitu di lapangan dan di Laboratorium Hama dan Penyakit Tumbuhan Fakultas Pertanian, Universitas Pattimura. Sampel tanaman diperoleh dari beberapa kebun petani di wilayah Kota Ambon. Hasil penelitian yang diperoleh adalah bahwa jamur endofitik Trichoderma sp, Aspergillus sp, Penicillium sp, Diplodia sp dan Mucor sp. memiliki daya penghambatan yang berbedabeda, yaitu $78.57 \%$ (Trichoderma sp), 65.86\% (Penicillium sp), 43.29\% (Aspergillus sp), 36.71 (Diplodia sp) dan $34.44 \%$ (Mucor sp).

Kata kunci: antagonisme, identifikasi, jagung, jamur endofitik, jamurpatogenik, Rhizoctonia solani

\section{PENDAHULUAN}

Jagung berasal dari Amerika Tengah yang kemudian tersebar ke Asia dan Afrika bersamaan dengan kegiatan bisnis orang-orang Eropa ke Amerika.
Pada abad ke-16 jagung disebarkan oleh orang Portugal ke Negara-negara di Asia termasuk Indonesia (Iriyanni et al. 2006). Jagung merupakan tanaman serelia yang termasuk bahan pangan penting karena merupakan sumber karbohidrat kedua setelah beras. Sebagai salah 
satu sumber bahan pangan, jagung telah menjadi komoditas utama (Purwono et al., 2011). Tanaman serealia ini biasa tumbuh hampir di seluruh dunia. Beberapa daerah penghasil utama jagung di indonesia antara lain: Jawa Barat, Jawa Tengah, Jawa Timur, Madura, Daerah Istimewa Yogyakarta, Nusa Tenggara Timur, Sulawesi Utara, Sulawesi Selatan, dan Maluku. Selain sebagai bahan pangan, jagung juga dikenal sebagai salah satu bahan pakan ternak dan industri (Bakhri, 2007).

Penurunan produksi jagung terjadi hampir di seluruh negara produsen jagung di dunia, namun secara nasional kebutuhan jagung di Indonesia mengalami peningkatan (Winarso, 2012). Meningkatnya kebutuhan jagung di Indonesia disebabkan oleh makin tingginnya permintaan dari industri pakan ternak (Departemen Pertanian, 2007 dalam Umiyasih dan Wina, 2008). Menurut data statistik, produksi jagung di Maluku tahun 2015 sebesar 13.947 ton pipilan kering, meningkat sebanyak 3.379 ton dibandingkan tahun 2014. Peningkatan produksi terjadi karena produktivitas mengalami peningkatan 14.93 kuintal per hektar, walaupun mengalami penurunan luas panen seluas sebesar 535 hektar. Peningkatan produksi jagung tahun 2015 sebesar 3.379 ton terjadi pada bulan Januari-April sebesar 3.533 ton, sedangkan pada bulan Mei-Agustus mengalami penurunan sebesar 1.49 ton dibandingkan produksi pada tahun 2014 (BPS Maluku, 2016).

Upaya peningkatan produksi tanaman serealia terutama jagung sebagai bahan pangan, pakan, dan industri, perlu mendapat perhatian yang serius baik petani maupun pengguna prodak. Kenyataannya di lapangan, budidaya jagung dihadapkan pada berbagai penyakit tanaman, sehingga dapat menurunkan kuantitas dan kualitas hasil, karena itu masalah penyakit merupakan salah satu faktor pembatas produksi dan mutu jagung. Munculnya penyakit itu sendiri merupakan pengaruh interaksi dari 5 faktor utama, yaitu patogen, inang, lingkungan, waktu dan. Penyakit berkembang dengan tingkat keparahan bervariasi dan diduga berkaitan erat dengan asupan teknologi yang diterapkan petani (Nuryanto, 2003).

Salah satu penyakit jagung yang sangat berbahaya adalah hawar upih atau busuk pelepah yang banyak ditemukan pada tiap musim tanam yang disebabkan oleh jamur tular tanah Rhizoctonia solani dan banyak menurunkan produksi tanaman jagung di lapangan. Pengendalian yang sering dilakukan adalah menggunakan pestisida sintetik berbahan dasar kimia. Akan tetapi, penggunaan pestisida sintetik sering menimbulkan pencemaran terhadap lingkungan (tanahtanah terkontaminasi), dan membunuh mikroorganisme bukan sasaran, selain berbahaya bagi pengguna (manusia). Menurut Soylu et al. (2005) dan Meyera et al. (2006), pestisida sintetik dapat memicu munculnya kelompok patogen dengan strain baru yang lebih resisten. Untuk itu, usaha pengendalian terhadap penyakit lebih diarahkan pada pengendalian yang ramah lingkungan dengan menggunakan agensia pengendalian hayati, yaitu mikroorganisme endofitik yang bersifat antagonis, juga dapat memacu pertumbuhan dan meningkatkan ketahanan tanaman. Mikroorganisme endofitik pertama kali dilaporkan di Darnel, Jerman, pada tahun 1904 (Tan dan Zou, 2001). Mikroorganisme endofitik merupakan mikroorganisme (jamur, bakteri) yang hidup dan berkembang dalam jaringan tanaman sehat dengan membentuk koloni yang tidak membahayakan inangnya dan dapat ditemukan pada bagian akar, batang, daun dan bunga (Selim et al., 2012).

Berkembangnya penelitian yang makin intens akhir-akhir ini tentang penggunaan mikroorganisme endofitik yang berpotensi meningkatkan ketahanan tanaman terhadap serangan patogen telah menjadi salah satu dasar perlunya penelitian eksplorasi dan identifikasi jamur endofitik asal jagung yang diduga juga berpotensi sebagai agensia pengendali hayati.

Tujuan penelitian ini adalah: (i) mengidentifikasi mikroorganisme endofitik pada jagung secara morfologi, (ii) mendapatkan mikroorganisme endofitik pada jagung, (ii) enguji kemampuan antagonisme jamur endofitik sebagai agensia pengendali hayati terhadap jamur Rhizoctonia solani penyebab penyakit busuk pelepah pada jagung.

\section{BAHAN DAN METODE}

\section{Tempat dan Waktu Penelitian}

Penelitian ini dilaksanakan di lapangan (Daerah Kota Ambon) dan Laboratorium Hama dan Penyakit Tumbuhan Fakultas Pertanian, Universitas Pattimura berlangsung pada bulan Januari - September 2018.

\section{Alat dan Bahan}

Bahan-bahan yang digunakan pada penelitian ini: tanaman jagung sehat (akar, batang dan daun), medium PDA, $\mathrm{NaOCl} 0,5 \%$, akuades, alkohol 70\% dan 95\%, tissue, kapas, kertas label, kertas saring. Alat-alat yang digunakan: cawan petri, tabung reaksi, labu Erlenmeyer, pipet, alumunium foil, gelas ukur, jarum preparat, mikroskop, autoclave, timbangan digital, alat tulis menulis, kamera, pengaris, gunting, skapel, blate no 11 .

\section{Metode Penelitian}

Isolasi jamur endofitik dilakukan dengan metode Yunianto et al. (2012). Jamur endofitik diisolasi dari tanaman jagung sehat bagian akar, batang, dan daun. Sampel dibersihkan pada air mengalir, dikeringanginkan, selanjutnya disterilisasi permukaannya menggunakan alkohol $70 \%$ dan direndam di dalam natrium hipoklorit $0,5 \%$ selama 2 menit. Sampel dibilas dengan aquades steril sebanyak 3 kali dan dikeringkan di atas kertas saring steril, kemudian batang dan akar sampel jagung dikupas, dipotong dengan ukuran \pm 5 $\mathrm{mm}$, dibelah dan ditumbuhkan pada media PDA pada empat titik. 


\section{Uji Antagonisme Jamur Endofitik terhadap Rhizoctonia solani}

Tahapan pengujian menggunakan metode biakan ganda (dual culture) dengan cara mengambil masingmasing biakan murni hasil karakterisasi yang tergolong jamur antagonis dan jamur patogen menggunakan bor gabus berdiameter $5 \mathrm{~mm}$; kemudian diinokulasikan ke dalam cawan petri yang berisikan medium PDA secara berhadapan dengan jarak $2 \mathrm{~cm}$ dari pinggiran cawan petri (Gambar 1).
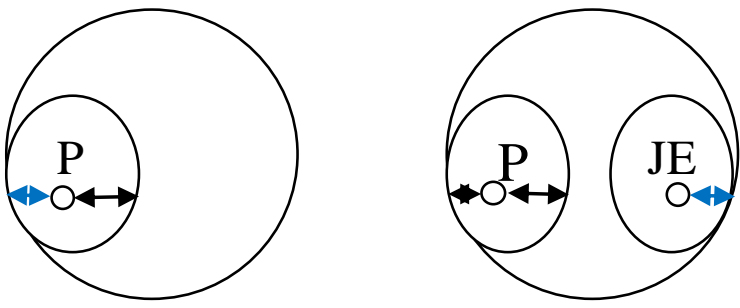

Gambar 1. Skema pengujian dual culture

Untuk mengetahui intensitas kerusakan penyakit busuk pelepah pada jagung dilakukan perhitungan dengan menggunakan formula berikut. Pengamatan dilakukan setiap hari dengan mengukur pertumbuhan koloni untuk mengetahui persentase daya hambat jamur antagonis. Persentase hambatan dihitung berdasarkan formula yang dikemukakan oleh Alfizar et al. (2013), yaitu:

$$
\mathrm{P}=\frac{\mathrm{R}_{1}-\mathrm{R}_{2}}{\mathrm{R}_{1}} \times 100 \%
$$

Keterangan: $\mathrm{P}=$ Persentase penghambat pertumbuhan radial; $\mathrm{R} 1$ = Diameter pertumbuhan Jamur $R$. Solani pada perlakuan kontrol $(\mathrm{mm})$; dan $\mathrm{R} 2=$ Diameter $R$. solani pada tiap perlakuan $(\mathrm{mm})$.

\section{HASIL DAN PEMBAHASAN}

\section{Isolat Jamur Rhizoctonia solani}

Secara makroskopis, $R$. solani mempunyai hifa yang bersifat hialin. Pada pertumbuhan awal jamur ini membentuk gumpalan massa hifa berwarna putih, kumpulan hifa mengumpul menjadi satu membentuk struktur yang lebih besar membentuk sklerotia yang sangat tahan, dan kemudian berubah warna menjadi coklat kekuningan setelah tua. Hifa $R$. solani yang masih muda mempunyai percabangan, dengan diameter hifa 4-6 $\mu \mathrm{m}$ pada medium PDA. Sklerotium yang ditemukan berbentuk bulat. Pertumbuhan $R$. solani berlangsung sangat cepat. Isolat dapat tumbuh menutupi cawan Petri ukuran $9 \mathrm{~cm}$ dalam waktu tiga hari. Menurut Soenartiningsih (2009) bahwa, jamur $R$. solani dapat hidup selama beberapa tahun dengan memproduksi sklerotia di tanah dan jaringan tanaman.

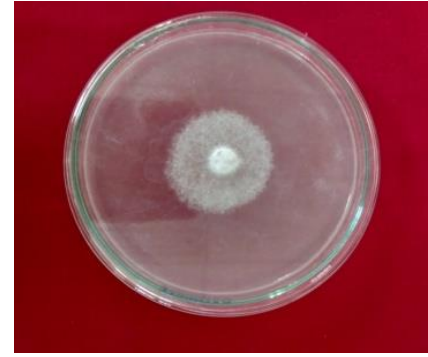

Gambar 2. Pertumbuhan jamur Rhizoctonia solani pada medium PDA

\section{Identifikasi Isolat Jamur Endofitik}

Pengamatan terhadap jamur endofitik yang diperoleh dari bagian tanaman jagung sehat dilakukakan secara makroskopis, untuk mengetahui antara lain warna koloni, bentuk koloni pada cawan Petri, tekstur koloni dan pertumbuhan koloni (cm/hari). Sedangkan pengamatan secara mikroskopis meliputi ada tidaknya septa pada hifa, pertumbuhan hifa, warna hifa dan konidia, ada atau tidaknya konidia, dan bentuk konidia. Hasil Isolasi jamur endofitik dari bagian tanaman jagung sehat dapat dilihat pada Tabel 1 .

Tabel 1. Hasil Isolasi Jamur Edofitik dari bagian tanaman Jagung sehat

\begin{tabular}{ccl}
\hline Jenis Isolat & Bagian Tanaman & Daerah Asal \\
\hline Isolat A & Akar & Poka \\
Isolat B1 & Batang & Poka \\
Isolat B2 & Batang & Wailete \\
Isolat D1 & Daun & Wailete \\
Isolat D2 & Daun & Telaga kodok \\
\hline
\end{tabular}

\section{Isolat $A$}

Ciri-ciri isolat A berwarna hijau tua keputihan, permukaan koloni tebal, kasar dan memperlihatkan laju pertumbuhan yang relatif lebih cepat. Bentuk koloni bulat, konidiofor bercabang tidak teratur. Hasil pengamatan morfologi jamur Trichoderma sp. Baik secara makroskopis maupun mikroskopis dapat dilihat pada Gambar 3.

\section{Isolat B1}

Isolat B1memiliki ciri-ciri berwarna putih pada awal pertumbuhan, kemudian berubah warna menjadi hijau kekuningan. Permukaan koloni halus dan kering berserbuk, bentuk koloni filamen hifa tidak bersepta, konidiofor tidak bercabang, spora bersel 2-3, ujung konidia berbentuk radial dan konidia berbentuk bulat. Hasil pengamatan karakteristik secara makroskopis dan mikroskopis jamur tersebut adalah Aspergillus sp. (Gambar 4). 


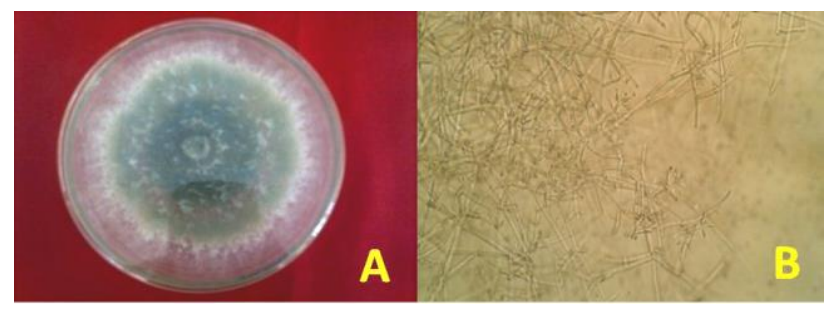

Gambar 3. Isolat A (Trichoderma sp.) asal akar jagung; A) koloni jamur Trichoderma sp. pada medium PDA; B) spora Trichoderma sp. (perbesaran 400x)

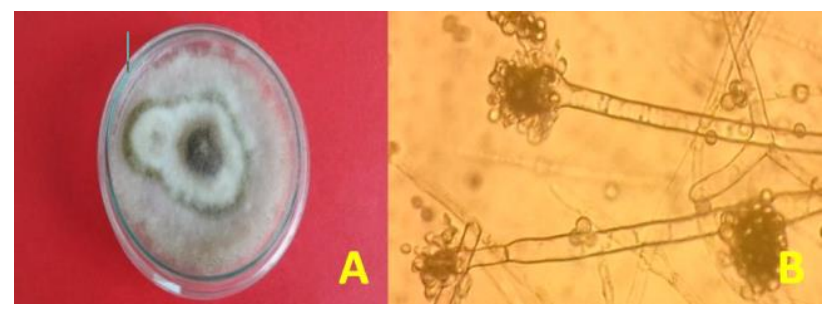

Gambar 4. Isolat B1(Aspergillus sp.) asal batang jagung; A) koloni pada medium PDA; B) konidiofor (pembesaran 400x)

\section{Isolat B2}

Isolat B2 memiliki ciri-ciri warna koloni hijau kebiruan, permukaan koloni halus seperti beludru atau kapas dan pengamatan secara mikroskopis memiliki konidiofor membentuk vesikel dibagian ujung dengan jumlah yang bervariasi, hifa bersepta, konidia berbentuk bulat. Secara makroskopis dan mikroskopis hasil pengamatan menunjukkan bahwa jamur tersebut adalah Penicillium sp. (Gambar 5).

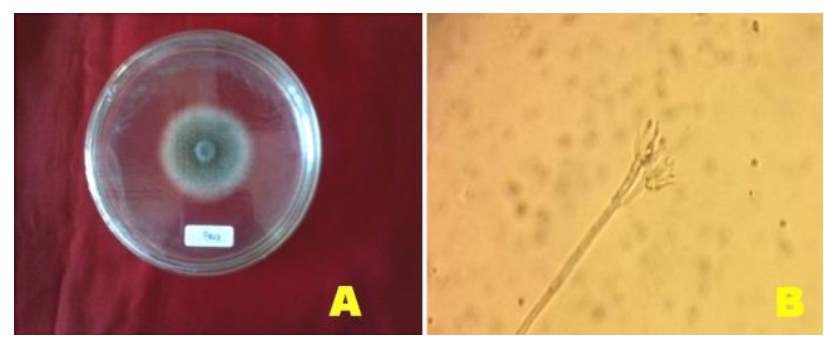

Gambar 5. Isolat B2 (Penicillium sp.) asal batang jagung; A) koloni pada medium PDA; B) spora (perbesaran 400x)

\section{Isolat D1}

Isolat dengan warna koloni kuning membentuk lingkaran putih, permukaan koloni tebal dan kasar, konidiofor bercabang hasil pengamatan secara makroskopis dan mikroskopis jamur tersebut adalah Diplodia sp. (Gambar 6).

\section{Isolat D2}

Isolat D2 mempunyai ciri-ciri berwarna hijau, permukaan koloni bertepung halus kering dan berserbuk, bentuk koloni berfilamen, hifa tidak bersekat, sporangiofor bercabang.

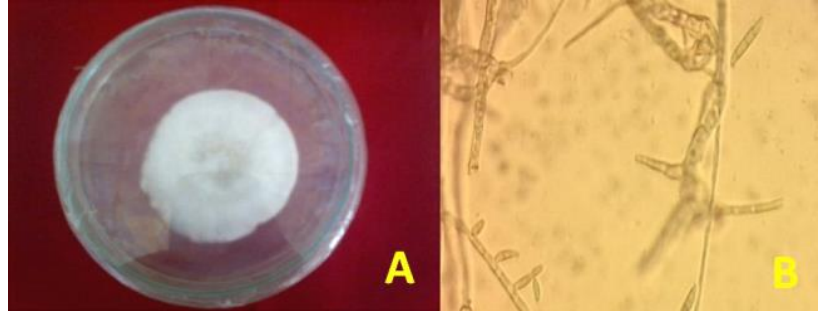

Gambar 6. Isolat D1 (Diplodia sp.) asal daun jagung; A) koloni pada medium PDA; B) spora (perbesaran 400x)
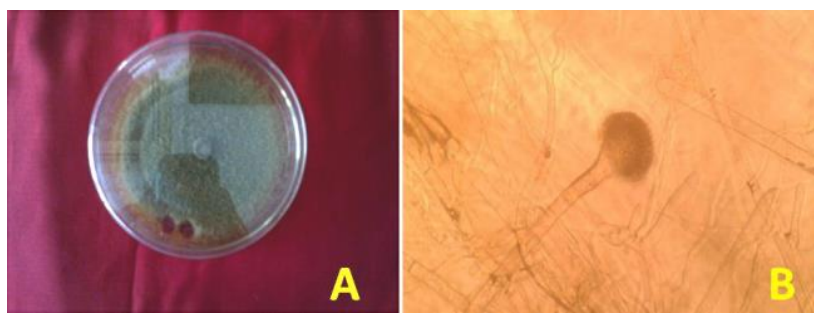

Gambar 7. Isolat D2 (Mucor sp.) asal daun jagung; A) koloni pada medium PDA; B) spora (perbesaran 400x)

Hasil pengamatan menunjukkan ciri-ciri makroskopis dan mikroskopis tersebut adalah jamur Mucor sp. (Gambar 7).

Hasil identifikasi secara mikroskopis dapat dilihat pada Tabel 2.

Tabel 2. Hasil identifikasi secara mikroskopis

\begin{tabular}{llll}
\hline \multicolumn{2}{c}{ Jenis Isolat Nama Isolat } & $\begin{array}{c}\text { Bagian } \\
\text { Tanaman }\end{array}$ & Daerah Asal \\
\hline Isolat A & Trichoderma sp. & Akar & Poka \\
Isolat B1 & Aspergillus sp. & Batang & Poka \\
Isolat B2 & Penicillium sp. & Batang & Wailete \\
Isolat D1 & Diplodia sp. & Daun & Wailete \\
Isolat D2 & Mucor sp. & Daun & Telaga kodok \\
\hline
\end{tabular}

Keberadaan populasi jamur endofitik sangat bervariasi pada setiap tumbuhan dengan spesies yang sama maupun berbeda. Kehadiran jenis endofitik dihubungkan dengan kondisi mikrohabitat tanaman inang dan kecocokan genotip antara tanaman inang dan endofitik. Kekayaan dan kelimpahan mikroorganisme endofitik pada tanaman dapat dipengaruhi oleh faktor biotik maupun faktor abiotik. Faktor biotik terdiri dari varietas dan spesies dari inang itu sendiri, umur tanaman serta bagian tanaman yang diisolasi. Sedangkan faktor abiotik yang dapat mempengaruhi antara lain faktor suhu, kelembaban relatif, dan kadar air tanah serta teknik budidaya.

\section{Uji Antagonisme Jamur Endofitik Terhadap Rhizoctonia solani}

Mikroorganisme yang bersifat antagonistik dapat digunakan sebagai agensia pengendali hayati untuk patogen tanaman. Uji antagonis dilakukan terhadap $R$. 
solani dengan jamur endofitik yang didapat dari tanaman jagung dengan pengujian biakan ganda (dual culture). Uji biakan ganda dilakukan antara patogen dengan jamur endofitik yang terdapat dalam satu cawan Petri berdiameter $9 \mathrm{~cm}$ dengan jarak peletakkan $2 \mathrm{~cm}$ dari pinggiran cawan Petri, baik untuk koloni patogen maupun koloni endofitik. Pengamatan secara makroskopis dilakukan setiap hari selama 4 hari masa inkubasi.

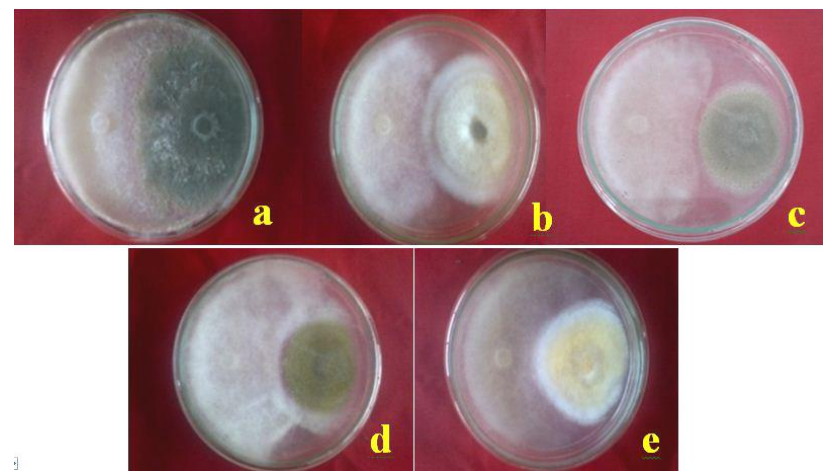

Gambar 8. Uji antagonis jamur endofitik terhadap $R$. solani dengan biakan ganda: a) $\mathrm{Uji}$ antagonis jamur Trichoderma $\mathrm{sp}$. dan $R$. solani; b) Uji antagonis jamur Aspergillus sp. dan R. solani; c) Uji antagonis jamur Penicillium sp. dan $R$. solani; d) Uji antagonis jamur Diplodia sp. dan R. solani; e) Uji antagonis jamur Mucor sp. dan $R$. solani

Jamur endofitik dapat berperan sebagai agensia biokontrol yang memberikan pengaruh yang sangat positif dalam menekan pertumbuhan beberapa patogen tanaman; selain itu juga mampu memicu pertumbuhan tanaman. Jamur endofitik telah banyak dimanfaatkan untuk mengendalikan jamur (Gaziz et al., 2010). Hal ini dapat dilihat dari hasil uji antagonis yang dilakukan dengan metode biakan ganda (dual culture) antara jamur endofitik dengan jamur patogen $R$. solani (Gambar 8). Semua isolat endofitik mampu menghambat isolat jamur patogen $R$. solani dengan mekanisme penghambatan yang berbeda-beda, yaitu mekanisme memarasit patogen secara langsung, memproduksi antibiotik, kompetisi ruang dan nutrisi, produksi enzim dan menginduksi respon ketahanan tanaman.

Perbedaan penghambatan yang terbentuk diduga karena masing-masing isolat endofitik mempunyai metabolit sekunder yang merupakan senyawa antibiotik yang berbeda-beda. Metabolit sekunder yang dihasilkan oleh jamur endofitik merupakan senyawa antibiotik yang mampu melindungi tanaman dari serangan patogen, di samping juga terdapat faktor lain yang mempengaruhinya. Hal ini sesuai dengan Kasutjianingati (2004) yang menyatakan bahwa faktor yang mempengaruhi ketidakefektifan agensia hayati dalam menghambat pertumbuhan patogen berupa antibiotik yang diproduksi oleh jamur endofitik kurang efektif terhadap patogen di antaranya karena konsentrasi antibiotiknya rendah dan terurai oleh mikroorganisme lain.

Tabel 3. Uji daya hambat aktivitas jamur endofitik terhadap R. solani

\begin{tabular}{cc}
\hline Kode isolat & Daya hambat $(\%)$ \\
\hline A & 78.57 \\
B1 & 65.86 \\
B2 & 43.29 \\
D1 & 36.71 \\
D2 & 34.44 \\
\hline
\end{tabular}

Dari hasil uji antagonis pada media biakan ganda antara jamur Trichoderma sp. dan $R$. solani menunjukkan mekanisme kompetisi dan parasitisme, dimana pertumbuhan Trichoderma sp. hampir memenuhi seluruh ruang uji atau permukaan media dengan daya hambat tertinggi, yaitu $78.57 \%$ pada hari keempat. Hal ini membuktikan, bahwa jamur endofitik dapat menekan pertumbuhan patogen, sesuai dengan yang dikemukakan oleh Amin et al. (2011) bahwa jamur yang tumbuh cepat mampu mengungguli dalam penguasaan ruang dan pada akhirnya dapat menekan pertumbuhan jamur lawannya. Persaingan yang terjadi disebabkan oleh adanya kebutuhan akan nutrisi yang terkandung dalam media uji untuk keberlangsungan hidupnya. Menurut Soesanto (2008), persaingan terjadi ketika terdapat dua atau lebih mikroorganisme dalam satu media yang secara langsung memerlukan sumber nutrisi yang sama dari media. Miselium Trichoderma sp. cenderung lebih luas dibandingkan miselium $R$. solani. Hal ini diduga karena adanya kemampuan Trichoderma sp. menghasilkan asam organik tertentu yang tidak dapat dimanfaatkan oleh $R$. solani serta kemampuan Trichoderma sp. untuk menghasilkan metabolit sekunder berupa antibiotik yang menghambat perkecambahan spora jamur $R$. solani.

Tripathi et al. (2008) dan Grosch et al. (2006) melaporkan bahwa, jamur endofitik Trichoderma sp. mempunyai kemampuan memarasit hifa patogen $R$. solani. Menurut Faeth (2002) bahwa jamur endofitik mempunyai aktivitas antonistik yang cukup tinggi dalam menghasilkan enzim yang dapat digunakan untuk mengendalikan patogen.

Mekanisme penghambatan pertumbuhan $R$. solani oleh jamur endofitik secara antibiosis dicirikan oleh zona bening di sekitar zone pertemuan jamur endofitik dengan patogen. Ini terlihat pada jamur Penicillium sp. dan Aspergillus sp. dengan daya hambat Penicillium sp. 43.29\% dan daya hambat Aspergillus sp. 65.86\%. Hal ini sesuai dengan Maria (2002) yang menyatakan bahwa terbentuknya zona hambat menandakan bahwa agensia biokontrol memproduksi suatu senyawa antimikrobial baik berupa enzim, toksin maupun antibiotik. Mekanisme lain yang ditunjukan oleh jamur Diplodia sp. $(37.71 \%)$ dan Mucor sp. dengan daya hambat terendah, yaitu $34.44 \%$. Pada uji antagonis terjadi mekanisme kompetisi yang dicirikan dengan lambatnya 
pertumbuhan jari-jari patogen yang menuju jamur endofitik. Hal ini didukung oleh pernyataan Octriana (2011), bahwa kompetisi antara agensia hayati dengan patogen menyebabkan patogen tidak memiliki ruang untuk tempat hidupnya sehingga pertumbuhannya terhambat.

Dilihat dari daya hambat dan mekanisme penghambatan, tiap isolat endofitik yang berbeda-beda. Hal ini menunjukkan bahwa kelima isolat jamur endofitik, yaitu Trichoderma, Aspergillus sp., Penicillium sp., Diplodia sp. dan Mucor sp. mengandung senyawa antibiotik yang berbeda-beda. Selain itu, mikroorganisme antagonis dapat menggunakan satu atau lebih mekanisme untuk menekan patogen. Daya hambat jamur antagonis terhadap patogen secara in vitro ini menjadi salah satu indikator kemampuannya untuk menekan pertumbuhan patogen di lapangan.

\section{KESIMPULAN DAN SARAN}

Berdasarkan hasil penelitian maka dapat disimpulkan bahwa:

1. Hasil isolasi jamur endofitik dari bagian tanaman jagung sehat baik akar, batang dan daun yang diperoleh sebanyak lima jenis isolat.

2. Berdasarkan karakteristik mikroskopis dan makroskopis diduga bahwa isolat A adalah Trichoderma sp., isolat B1 adalah Aspergillus sp, B2 adalah penicillium sp, D1 adalah Diplodia sp dan isolat D2 adalah Mucor sp.

3. Kelima isolat jamur endofitik tersebut memiliki kemampuan yang berbeda-beda dalam menekan pertumbuhan patogen. Penghambatan tertinggi terhadap jamur patogen $R$, solani dicapai oleh Trichoderma sp. sebesar $78.57 \%$. berikut:

Saran-saran dari penelitian ini adalah sebagai

1. Disarankan untuk penelitian yang sama tetapi pada tanaman yang berbeda.

2. Perlu penelitian lanjutan tentang kelima jamur endofitik sebagai agensia pengendalian hayati pada penyeakit busuk pelepah tanaman lainnya.

\section{DAFTAR PUSTAKA}

Alfizar, Marlina, dan F. Susanti. 2013. Kemampuan antagonis Trichoderma sp. terhadap beberapa jamur patogen in vitro. Jurnal Floratek 8: 45-51.

Amin, N. Asman dan A. Thamrin. 2011. Isolasi dan identifikasi cendawan endofit dari klon tanaman kakao tahan VSD M.05 dan klon rentan VSD M.01. Fakultas Pertanian. Universitas Hasanuddin, Makassar.

Ariyanto, E.F., A.L. Abadi, dan S. Djauhari. 2013. Keanekaragaman cendawan endofit pad tanaman padi (Oryza sativa L.) dengan sistem pengelolaan hama terpadu (PHT) dan konvensional di Desa
Bayem, Kecamatan Kasembon, Kabupaten Malang. Jurnal PHT 1(2): 37-51.

Badan Pusat Statistik Provinsi Maluku. 2016. Provinsi Maluku Dalam Angka 2016. Badan Pusat Statistik Provinsi Maluku, Ambon.

Barnett, H.L., and B.B. Hunter. 1998. Illustrated Genera of Imperfect Fungi fourth ed. Burgess Publishing Company. Minneopolis. Minnesota.

Departemen Pertanian. 2007. Statistik Pertanian 2007. Pusat Data Statistik dan Informasi Pertanian, Departemen Pertanian, Jakarta.

Faeth SH. 2002. Are Endophytic Fungi Defensive Plant Mutualists? Oikos 98:25-36.

Gazis, R., and P. Chaverri. 2010. Diversity of fungal endophytes in leaves and stems of wild rubber trees (Hevea brasiliensis) in Peru. Fungal Ecology 3(1): 240-254. DOI: 10.1016/j.funeco. 2009.12.001

Grosch, R., K. Scherwinski, J. Lottmann and G. Berg. 2006. Fungal antagonists of the plant pathogen Rhizoctonia solani: selection, control efficacy and influence on the indigenous microbial community. Mycol. Res. 110: 1464-1474: DOI: 10.1016/j.mycres

Herre, E.A., L.C. Mejia, D.A. Kyllo, E. Rojas, Z. Maynard, A. Butler and S.A.Van Bael. 2007. Ecological Implications of anti-pathogen effects of tropical fungal endophytes and mycorrhizae. Ecology 88: 550-558. DOI: http://dx.doi.org/ 10.1890/05-1606

Iriyanni, R.N., M. Yasin, dan T. Andi. 2006. Asal, Sejarah, Evolusi, \& Taksonomi Tanaman Jagung. Balai Penelitian Tanaman Serealia. Maros.

Kasutjianingati. 2004. Pembiakan Mikroorganisme Genotipe Pisang (Musa spp.) dan Potensi Bakteri Endofit Terhadap Layu Fusarium (Fusarium oxysporum f.sp. cubense). Tesis. Sekolah Pascasarjana. Institut Pertanian Bogor, Bogor.

Maria, P.D. 2002. Eksplorasi dan uji Antagonis Bakteri Rhizosfer Tanah dan Endofit Akar untuk Pengendalian Penyakit Layu (F. oxysporum f.sp. cubense) Pada Pisang (Musa paradisiaca). Skripsi. Fakultas Pertanian, Institut Pertanian Bogor, Bogor.

Meyera, M.C., C.J. Buenob, N.L. de Souzab, and J.T. Yorinoric. 2006. Effect of doses of fungicides andplant resistance activators on the control of Rhizoctonia foliar blight of soybean and on Rhizoctonia solani AG1-IA in vitro development. Crop Protect. 25:848-854.

Noverita, D. Fitria dan E. Sinaga. 2009. Isolasi dan uji aktifitas antibakteri jamur endofit dari daun dan rimpang Zingiber ottensii Val. Jurnal Farmasi Indonesia 4(4): 171-176.

Nuryanto, B., A. 2003. Pengelolaan Kelompok Epidemik untuk Menekan Hawar Pelepah Daun Padi (Rhizoctonia solani). Tesis. Program Pasca Sarjana. Institut Pertanian Bogor, Bogor. 
Octriana, L. 2011. Potensi agens hayati dalam menghambat pertumbuhan Phytium sp. secara in vitro. Buletin Plasma Nuftah 17(2): 138-142.

Purwono, M. dan Hartono, R. 2007. Bertanam Jagung Manis. Penebar Swadaya. Bogor.

Selim, K.A., A.A. El-Beih, T.M. AbdEl-Rahman, and A.I. El-Diwany AI. 2012. Biologi of endophytic fungi. Current Research in Environmental \& Applied Mycology 31-82. DOI: 10.5943/2/1/3.

Smith, J. D., K. K. Kidwell., M.A. Evans., R.J. Cook and R. W. Smiley. 2003. Assessment of spring wheat genotypes for disease reaction to Rhizoconia solani AG-8. Crop Science 43(2): 701-709. DOI: https://doi.org/10.2135/ cropsci2003.7010.

Soenartiningsih. 2009. Histologi dan kerusakan oleh jamur $R$. solani penyebab penyakit busuk pelepah pada jagung. Prosiding Seminar Nasional Biologi XX dan Kongres Perhimpunan Biologi Indonesia XIV, 24-25 Juli 2009, Malang.

Soesanto, L. 2008. Pengantar Pengendalian Hayati Penyakit Tumbuhan. Raja Grafindo Persada, Jakarta.

Soylu, S., E.M. Soylu, S. Kurt and O.K. Ekici. 2005. Antagonistic potentials of rhizosphere-associated bacterial isolates against soilborne diseases of tomato and pepper caused by Sclerotinia sclerotiorum and Rhizoctonia solani. Pak. J. Biol. Sci. 8: 43-48.
Tan, R.X. and W.X. Zou. 2001. Endophytes: a rich source of functional metabolites. Nat. Prod. Rep. 18(4): 448-59. DOI: 10.1039/b100918o. PMID: 11548053.

Tondok, E.T. 2012. Keragaman Cendawan Endofit pada Buah Kakao dan Potensinya dalam Pengendalian Busuk Buah Phytophora. Disertasi. Institut Pertanian Bogor, Bogor.

Tripathi, S., S. Kamal, I. Sheramati, R. Oelmullerand, and A. Varma. 2008. Mycorrhizal fungi and other root endophytes as biocontrol agents against root pathogens. In: A Varma (Ed.), Mycorrhiza, p.281-306. New York: SpringerVerlag, Berlin Heidelberg.

Umiyasih, U. dan E. Wina. 2008. Pengolahan dan nilai nutrisi limbah tanaman jagung sebagai pakan ternak ruminansia. Wartazoa 18(3): 127-136.

Winarso. 2012. Prospek dan Kendala Pengembangan Agribisnis Jagung di Provinsi Nusa Tenggara Barat. Jurnal Penelitian Pertanian Terapan 12(2): 103-114.

Yunianto, P., S. Rosmalawati, I. Rachmawati, W.P. Suwarso dan W. Sumaryono. 2012. Isolation and identification of endophytic fungi from srikaya plants (Annona squamosa) having potential secondary metabolite as anti-breast cancer activity. Microbiology 6(1): 23-29. 